\title{
Cloning and characterization of filamentous temperature-sensitive protein Z from Xanthomonas oryzae pv. Oryzae
}

\author{
Leng Dai, Yunhong Huang, Yang Chen and Zhong-er Long*
}

\begin{abstract}
The ftsZ gene from Xanthomonas oryzae pv. Oryzae was amplified by PCR with the specific primers, and the recombinant plasmid pET-22b-ftsZ was constructed successfully. The Fts $Z$ with a $6 \times$ His tag was overexpressed in a soluble form in Escherichia coli BL21 and purified through a Ni-NTA agarose column. The purified recombinant FtsZ showed a single band on SDS-PAGE with an apparent molecular mass of about $44 \mathrm{kDa}$, and confirmed by western blotting analysis. The optimum temperature for GTPase activity of the recombined Fts $Z$ was $50^{\circ} \mathrm{C}$, and the optimum pH was 7.0. The recombinant FtsZ showed good stability and retained $>95 \%$ activity at $50^{\circ} \mathrm{C}$ for $240 \mathrm{~min}$. The GTPase activity followed Michaelis-Menten kinetics with the $\mathrm{K}_{\mathrm{M}}$ of $1.750 \mathrm{mM}$ and the $\mathrm{V}_{\max }$ of $0.155 \mathrm{nmol} \mathrm{Pi} / \mathrm{min} / \mathrm{nmol}$ Fts $Z$ respectively.
\end{abstract}

Keywords: FtsZ, Xanthomonas oryzae pv. Oryzae, Escherichia coli BL21, Expression

\section{Background}

The filamentous temperature-sensitive protein $\mathrm{Z}$ (FtsZ) plays an important role in the bacterial cell division. In the process of bacterial cell division, FtsZ forms singlestranded filaments and then the highly dynamic Z-ring scaffold, followed by the recruitment of other cell division proteins. Once the recruitment is accomplished, the filaments bend and $\mathrm{Z}$ ring contracts, leading to the closure of the septum and then the completion of the cell division, otherwise the bacterial cell division will be interrupted, which eventually result in bacterial apoptosis (Bi and Lutkenhaus 1991; Sossong et al. 1999). Due to its essential role and high conservation in bacteria, FtsZ is considered as an attractive target to develop the antibacterial agents with selective toxicity to bacterial pathogens (Margalit et al. 2004; Haydon et al. 2008; Kaur et al. 2010; Sass et al. 2011; Chan et al. 2013). Recently, a high-throughput screening model, based on inhibition of the GTPase activity of FtsZ, has been used to identify small molecules that target assembly-dependent GTPase

\footnotetext{
*Correspondence: Longzhonger@163.com

College of Life Science, Jiangxi Provincial Key Lab of Protection

and Utilization of Subtropical Plant Resources, Jiangxi Normal University,
}

Nanchang 330022, Jiangxi, China activity of FtsZ, and then FtsZ inhibitors were developed as antibacterial agents inducing bacterial lethality (Chan et al. 2013). This has elicited much interest among researchers for the cloning of FtsZ from all kinds of bacteria (Thakur and Chakraborti 2006; Kiran et al. 2009; Modia et al. 2014); however, there is little known about its enzymatic characteristics.

Xanthomonas oryzae pv. Oryzae is a causal agent of bacterial blight which is one of the most widespread and devastating bacterial diseases of rice plants in China and many other rice-growing countries (González et al. 2012). The research showed that the bacterial blight can wither the rice leaf, interfere with the photosynthesis, increase the false grain, decrease the grain quality and ruin grain's taste (Mew et al. 1993; Wu et al. 2013). Currently, the disease is managed by the use of resistant cultivars and antibacterial agents. However, the sensitivities of $X$. oryzae pv. Oryzae to the resistant cultivars and antibacterial agents have been found to decline, and resistant populations of $X$. oryzae pv. Oryzae have increased probably because of the wide use of the resistant cultivars and antibacterial agents, prompting a worldwide effort to develop new alternative antibacterial agents, especially with novel mechanisms of action (Davies 2011; Zhu et al. 2013).

\section{贷 Springer}

(c) 2016 Dai et al. This article is distributed under the terms of the Creative Commons Attribution 4.0 International License (http:// creativecommons.org/licenses/by/4.0/), which permits unrestricted use, distribution, and reproduction in any medium, provided you give appropriate credit to the original author(s) and the source, provide a link to the Creative Commons license, and indicate if changes were made. 
Here we report the cloning and characterization of FtsZ from $X$. oryzae pv. Oryzae. The fts $Z$ gene from $X$. oryzae pv. Oryzae was cloned, and expressed in Escherichia coli BL21 (DE3) by IPTG induction. The purified FtsZ was analyzed by SDS-PAGE and corfirmed by western-blotting. The GTPase activity of FtsZ was determined by measuring the Pi released from GTP catalysied by FtsZ, and the enzymatic characteristics of FtsZ were investigated.

\section{Results}

\section{Cloning of $f t s Z$ gene}

The genomic DNA of X. oryzae pv. Oryzae was extracted, and the concentration of DNA was detected by UV absorption at 280 and $260 \mathrm{~nm}$ by spectrophotometry (1100 UV/VIS, Shanghai). The density of genomic DNA was $81.8 \mu \mathrm{g} / \mu \mathrm{l}$, the ratio of $\mathrm{A}_{260 \mathrm{~nm}} / \mathrm{A}_{280 \mathrm{~nm}}$ was 1.91 , and then the genomic DNA was competent for PCR. The full length of an fts $Z$ gene was obtained by PCR using genomic DNA as a template. DNA sequencing showed that a $1261 \mathrm{bp}$ DNA fragment containing the fts $Z$ gene was amplified by PCR with the gene specific primers, which exhibited highest similarity to the fts $Z$ gene (gene ID: 3264933) from $X$. oryzae pv. Oryzae KACC10331 with $100 \%$ identity, indicating that the fts $Z$ gene had been obtained successfully and ligated into a pMD19-T vector to produce pMD19-ftsZ.

\section{Construction of recombinant expression vector}

The recombinant expression vector pET-22b-fts $Z$ was transformed into E. coli BL21 (DE3). The positive clones were identified by plasmid PCR and restriction enzymes digestion. The sequencing results further showed that the pET-22b-fts $Z$ expression vector was successfully constructed.

\section{Expression and purification of the recombinant FtsZ}

The recombinant vector $\mathrm{pET}$-22b-fts $Z$ was transformed into $E$. coli BL21 (DE3), and expressed in the transformed cells upon induction with IPTG at $37^{\circ} \mathrm{C}$. The IPTG was used in the pET vector system because of the T7 promoter. According to the characteristics of the expression vector $\mathrm{pET}-22 \mathrm{~b}(+)$ and the procedure for the construction of the expression vector, it can be predicted that there is a $6 \times$ His tag at the C-terminus of the expressed FtsZ (Termed the recombinant FtsZ), and the recombinant FtsZ can be purified by a Ni-NTA agarose column. The results of expression and purification of FtsZ were analyzed through SDS-PAGE (Fig. 1a). The FtsZ was expressed in E. coli BL21 (DE3)/pET22b- ftsZ induced by $0.6 \mathrm{mM}$ IPTG at $37{ }^{\circ} \mathrm{C}$, and determined in supernatant of lysed E. coli BL21 (DE3) cells containing pET-22b-ftsZ, which indicated that the fusion protein was produced

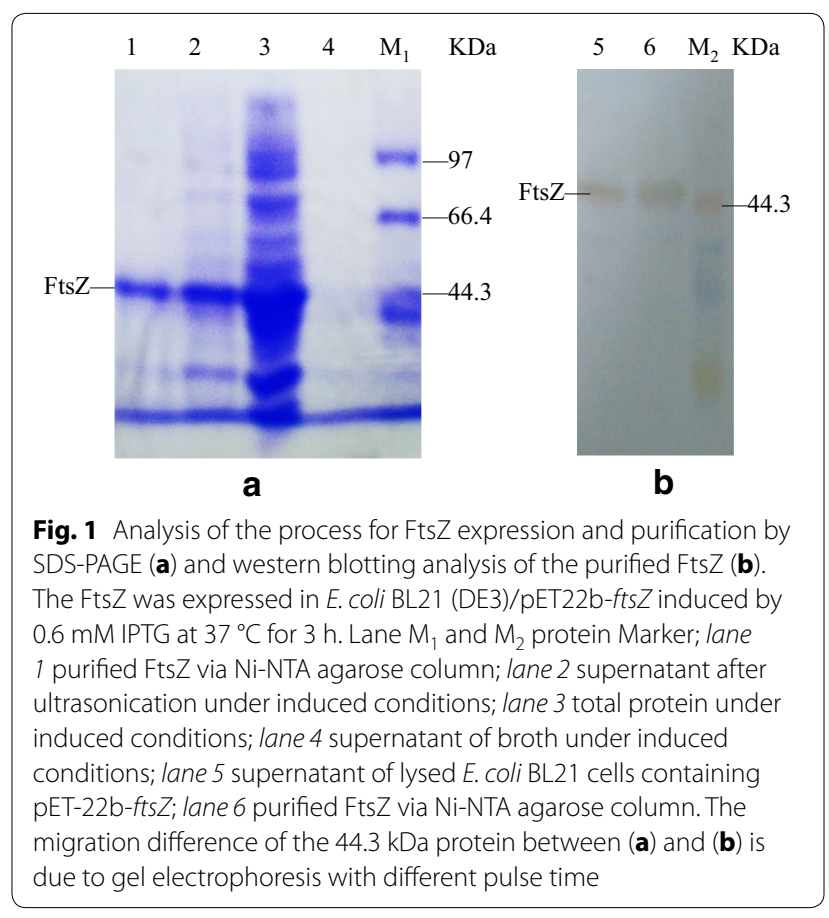

in a soluble form. The SDS-PAGE showed that the FtsZ exhibited one specific band with a molecular mass of about $44 \mathrm{kDa}$, which is close to the theoretical value calculated from the deduced amino acid sequences of the $f t s Z$ gene, indicating that it became electrophoretically pure. Meanwhile, the FtsZ was specifically recognized by the mouse anti-polyhistidine monoclonal antibody during the western blotting analysis (Fig. 1b), indicating that the FtsZ was indeed expressed in a recombinant protein with a $6 \times$ His tag.

\section{Bioinformatics of FtsZ}

The coding nucleotide sequence of the fts $Z$ gene and the corresponding predicted amino acid sequences of FtsZ were analyzed. Nucleotide sequence analysis of the $f t s Z$ gene revealed that the structural gene was composed of an open reading frame of $1242 \mathrm{bp}$. Analysis of the predicted protein sequence of FtsZ showed that it was composed of 422 amino acids with a predicted molecular mass of $43.967 \mathrm{kDa}$ and an isoelectric point of 5.09. The expressed FtsZ was the monomeric protein with a $6 \times$ His tag and containing 34 basic amino acids and 49 acidic amino acids. The stability coefficient and hydrophic index of FtsZ was 34.26 and -0.06 respectively, that is to say that FtsZ belongs to a stabilizing and hydrophobic protein. A GTP binding site of GGGTGTG was seen in the recombinant FtsZ based on the primary structure with the Clustal software analysis, which indicated that the FtsZ from $X$. oryzae pv. Oryzae could have GTPase activity. 
In addition, 3-D structural modelling of FtsZ was performed online with the Swiss-Model software (Fig. 2). The intricate spatial architecture showed that FtsZ contained 30.4\% $\alpha$-helical structure, $11.8 \% \beta$-sheet structure and $57.8 \%$ random coil structure, which was similar to FtsZ from other prokaryotes (Shin et al. 2013).

Based on the deduced amino acid sequences of FtsZ from $X$. oryzae pv. Oryzae and other FtsZ, a neighbourjoining (NJ) tree was constructed, with the MEGA5.1 program, to investigate the evolutionary relationships (Fig. 3). The results revealed that FtsZ from $X$. oryzae pv. Oryzae was derived from the same ancestor as other FtsZ in microorganisms and had close relationship with the FtsZ from X. campestris str. ATCC 33913, which is consistent with the evolution of species.

\section{Enzymatic characteristics of the recombinant FtsZ}

The temperature had a remarkable effect on the GTPase activity and the stability of the recombinant FtsZ (Fig. 4).

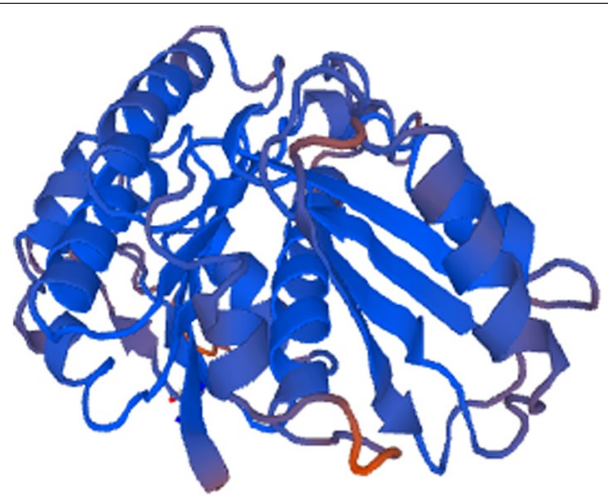

Fig. 2 The proposed 3-D structural model of FtsZ. 3-D structural modelling of Fts Z was performed online with the Swiss-Model software
The optimum temperature for the GTPase activity of the recombinant FtsZ was about $50{ }^{\circ} \mathrm{C}$. Meanwhile the recombinant FtsZ retained $100 \%$ GTPase activity at $4{ }^{\circ} \mathrm{C}$ and $>95 \%$ at $50{ }^{\circ} \mathrm{C}$ for $240 \mathrm{~min}$, whereas it rapidly lost its GTPase activity at $60^{\circ} \mathrm{C}$ or higher.

The effect of $\mathrm{pH}$ on the GTPase activity of the recombinant FtsZ was shown in Fig. 5. It can be seen that the GTPase activity of the recombinant FtsZ increased with the increase of $\mathrm{pH}$. The recombinant FtsZ had the best GTPase activity when the $\mathrm{pH}$ was 7.0, and quickly lost its activity at $\mathrm{pH}>9.0$. Therefore, $\mathrm{pH} 7.0$ was selected as the optimum $\mathrm{pH}$.

Further, the effect of $\mathrm{Mg}^{2+}$ on GTPase activity of the recombinant FtsZ from $X$. oryzae pv. Oryzae was shown in Fig. 6. The GTPase activity of the recombinant FtsZ was increased by the addition of $\mathrm{Mg}^{2+}$. Thus, $\mathrm{Mg}^{2+}$ seems to be a co-factor of the intrinsic GTPase activity present in the recombinant FtsZ.

The GTPase activity of the recombinant FtsZ was measured with an increasing concentration of GTP under the above optimal conditions. The kinetic constants were analysed by fitting to the Michaelis-Menten kinetics (Fig. 7) and it could be determined that the values of $\mathrm{K}_{\mathrm{M}}$ and $\mathrm{V}_{\max }$ were $1.68 \mathrm{mM}$ and $0.155 \mathrm{nmol} \mathrm{Pi} / \mathrm{min} / \mathrm{nmol}$ of the recombinant FtsZ, respectively.

\section{Discussion}

As it can be polymerized to form a $\mathrm{Z}$ ring acting as an essential skeleton during cell division, and is widely conserved in the bacterial kingdom, FtsZ is considered as an attractive target to develop the antibacterial agents with selective toxicity to bacterial pathogens and it has inspired many interests among researchers for the expression of FtsZ in vitro (Thakur and Chakraborti 2006; Kiran et al. 2009; Modia et al. 2014). According to

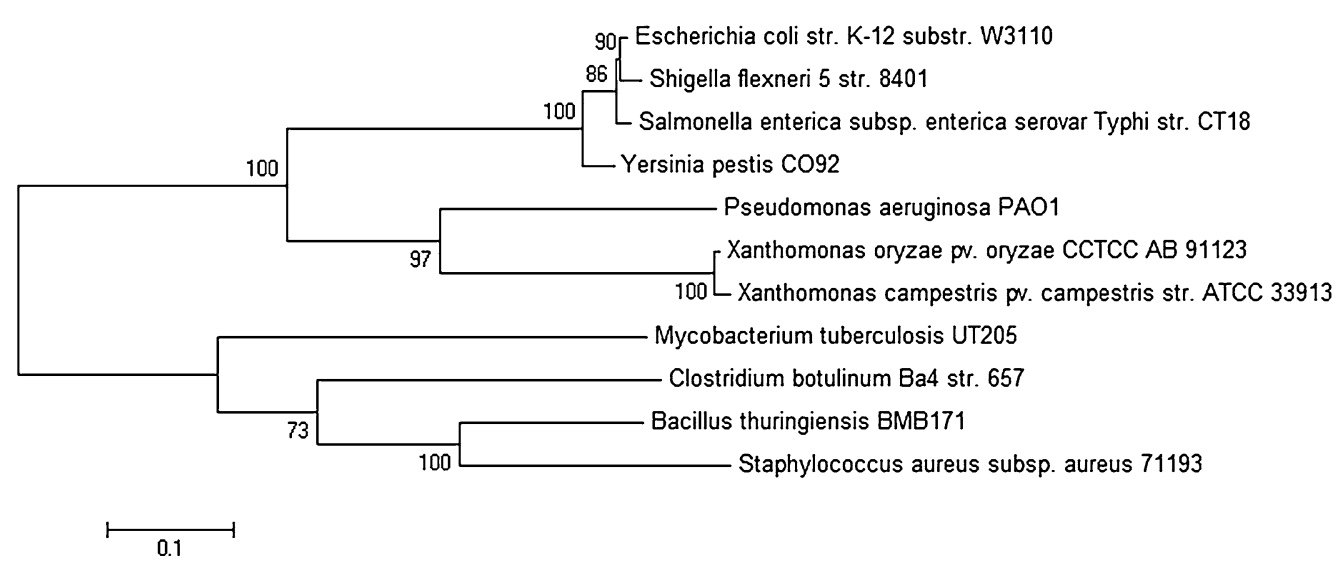

Fig. 3 Phylogenetic analysis of FtsZ from X. oryzae pv. Oryzae. DNAMAN and MEGA5.1 software were used for phylogenetic analysis with the neighbour-joining method 

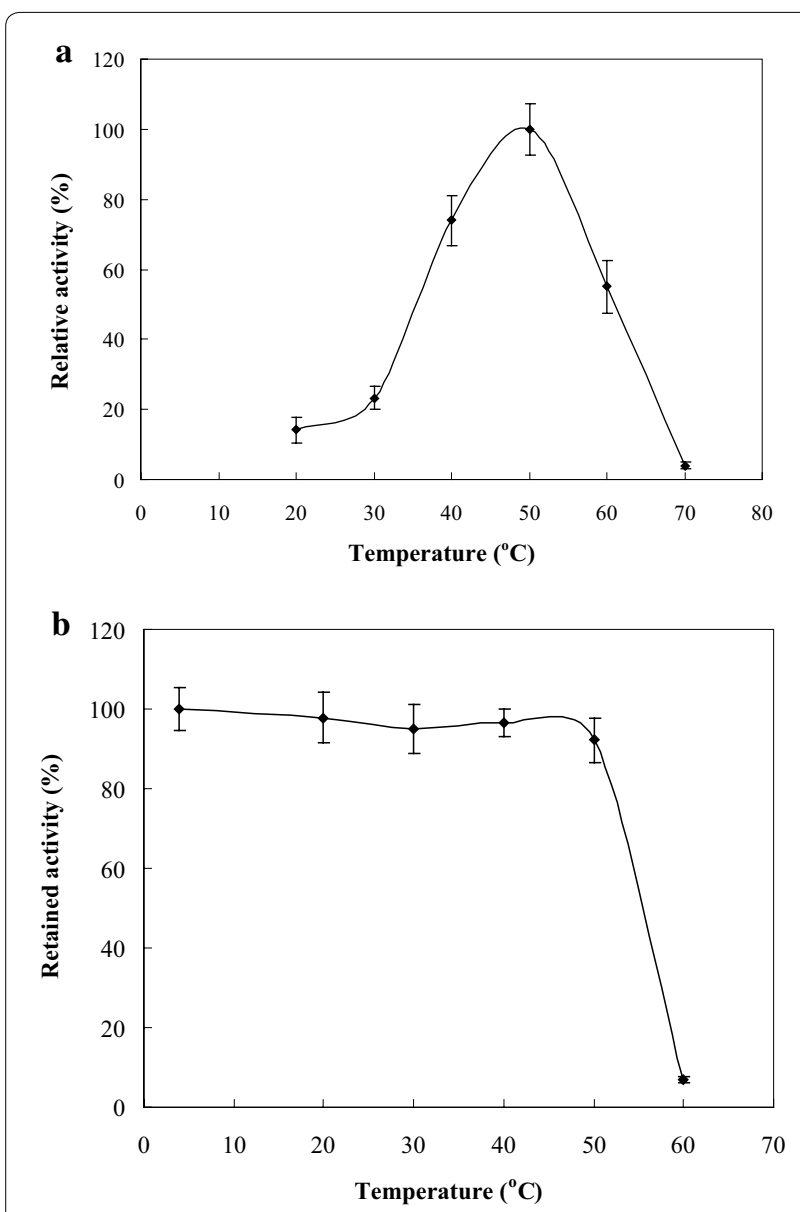

Fig. 4 Effect of temperature on the GTPase activity (a) and the stability (b) of the recombinant FtsZ. The effect of temperature on GTPase activity of the recombinant Fts $Z$ was determined by the GTPase activity assay with $5 \mathrm{mM} \mathrm{GTP}$ in buffer solution $(\mathrm{pH} 7.0)$ as substrate at temperature range of $20-70{ }^{\circ} \mathrm{C}$, thermal stability of the recombinant Fts $Z$ was determined by measuring the retained GTPase activity after incubation at $4-60{ }^{\circ} \mathrm{C}$ for $240 \mathrm{~min}$. The relative GTPase activity of the recombinant FtsZ is the ratio of the GTPase activity at certain temperature and at optimum temperature (a), the retained GTPase activity of the recombinant Fts $Z$ is the ratio of the GTPase activity after and before treatment $(\mathbf{b})$

the results of the literature survey, it is the first report on the expression in vitro of FtsZ from $X$. oryzae pv. Oryzae in this paper.

The dynamics of FtsZ polymerization depends on its properties as a GTPase. Therefore, the characteristics of the GTPase activity of FtsZ (in the form of the recombinant protein) were studied in this paper.

Firstly, based on the coding nucleotide sequence of the fts $Z$ gene and the corresponding predicted amino acid sequences, the structural characteristics of Fts $Z$ from $X$. oryzae pv. Oryzae were analyzed by bioinformatics methods. The results showed that the structure of FtsZ from $X$. oryzae pv. Oryzae was similar to those from other

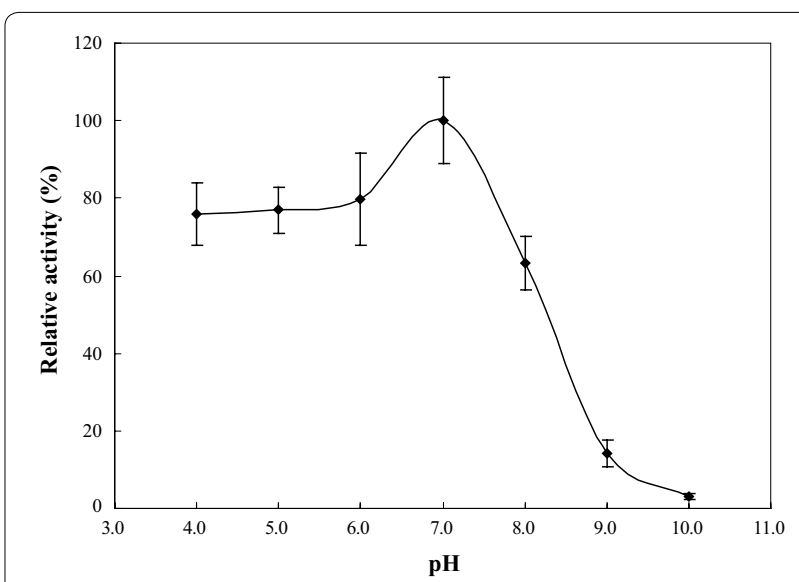

Fig. 5 Effect of pH on the GTPase activity of the recombinant FtsZ. The effect of $\mathrm{pH}$ on GTPase activity of the recombinant Fts $Z$ was determined by the GTPase activity assay with $5 \mathrm{mM}$ GTP as substrate in the $\mathrm{pH}$ range of $4.0-10.0$ at $50^{\circ} \mathrm{C}$. The relative GTPase activity of the recombinant Fts $\mathrm{Z}$ is the ratio of the GTPase activity at a certain $\mathrm{pH}$ and at optimum $\mathrm{pH}$

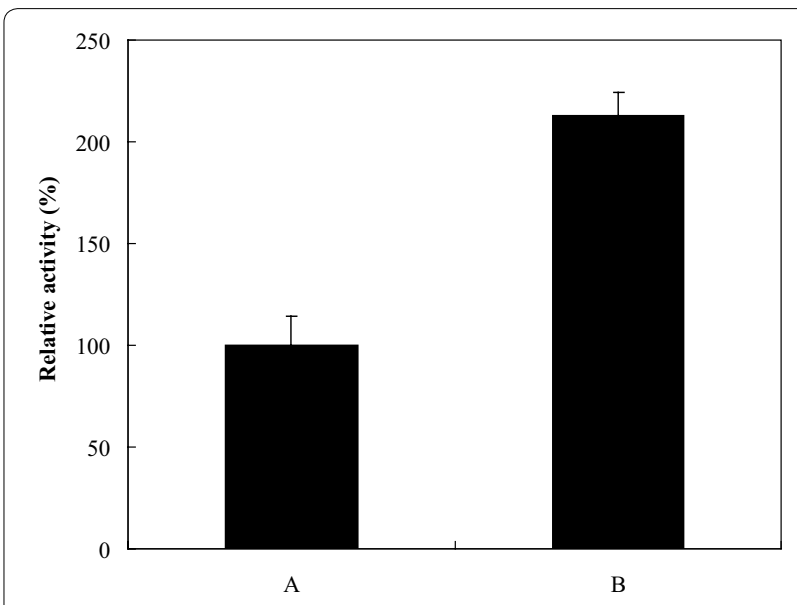

Fig. 6 Effect of $\mathrm{Mg}^{2+}$ on the GTPase activity of the recombinant FtsZ. The effect of $\mathrm{Mg}^{2+}$ on GTPase activity of the recombinant FtsZ was determined by measuring the GTPase activity of FtsZ in the presence of $\mathrm{Mg}^{2+}$ at final concentration of $0 \mathrm{mM}(\mathbf{a})$ and $5 \mathrm{mM}(\mathbf{b})$ using the GTPase activity assay at $50^{\circ} \mathrm{C}$ and $\mathrm{pH}$ 7.0. The relative GTPase activity of the recombinant FtsZ is the ratio of the GTPase activity in the presence and absence of $\mathrm{Mg}^{2+}$

bacteria, and the neighbour-joining tree showed that the phylogenetic relationships of FtsZ from different sources were consistent with the evolution of species (Fig. 5).

Secondly, the optimal conditions for the GTPase activity of FtsZ from $X$. oryzae pv. Oryzae were investigated, and the results showed that the optimum $\mathrm{pH}$ is 7.0 and the optimum temperature is about $50{ }^{\circ} \mathrm{C}$. In addition, $\mathrm{Mg}^{2+}$ seems to be a co-factor of the intrinsic GTPase activity present in the recombinant FtsZ, which was similar to that of Deinococcus radiodurans (Modia et al. 2014). 


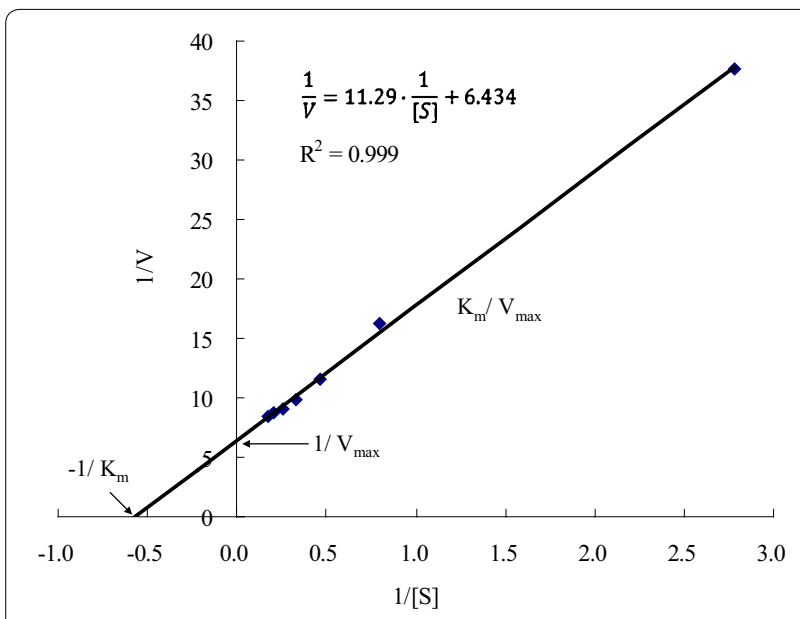

Fig. 7 Analysis of the enzyme kinetic constants of the recombinant FtsZ. Michaelis-Menten kinetic experiments on GTPase activity of the recombinant Fts $Z$ were performed with final concentration of 1-10 mM GTP as substrate at $50^{\circ} \mathrm{C}$ and $\mathrm{pH} 7.0$, and the kinetics $\mathrm{K}_{\mathrm{M}}$ and $\mathrm{V}_{\max }$ were calculated

Thirdly, based on the Michaelis-Menten equation, the values of $\mathrm{K}_{\mathrm{M}}$ and $\mathrm{V}_{\max }$ for the GTPase activity from $X$. oryzae pv. Oryzae FtsZ were $1.750 \mathrm{mM}$ and $0.155 \mathrm{nmol}$ $\mathrm{Pi} / \mathrm{min} / \mathrm{nmol}$ FtsZ, respectively. According to the results reported in the literature, the $\mathrm{V}_{\max }$ of Fts $Z$ from $X$. ory$z a e$ pv. Oryzae was lower than that of FtsZ from E. coli (19.758 $\mathrm{nmol} \mathrm{Pi/min/nmol} \mathrm{FtsZ),} \mathrm{from} \mathrm{Deinococcus} \mathrm{radi-}$ odurans $(3.7 \mathrm{nmol} \mathrm{Pi} / \mathrm{min} / \mathrm{nmol} \mathrm{FtsZ),} \mathrm{and} \mathrm{from} \mathrm{Myco-}$ bacterium tuberculosis $(0.273 \mathrm{nmol} \mathrm{Pi} / \mathrm{min} / \mathrm{nmol}$ FtsZ) (Modia et al. 2014), perhaps the maximum reaction rate is related to the speed of cell division.

\section{Conclusions}

The fts $Z$ gene from $X$. oryzae pv. Oryzae was cloned and overexpressed in E. coli BL21, the recombinant FtsZ was purified through a Ni-NTA agarose column, and we determined several biochemical properties of FtsZ, including the optimum parameters and kinetic constants of its intrinsic GTPase activity and structural protein features. The study may lay the foundation for further research and application of FtsZ from $X$. oryzae pv. Oryzae.

\section{Methods}

\section{Bacterial strains, plasmids and reagents}

Xanthomonas oryzae pv. Oryzae (CСТCC AB 91123) was obtained from China-Center for Type Culture Collection, Wuhan University (Wuhan, China), and cultured as previously described (Byul et al. 2011). Both E. coli DH5 $\alpha$ used for gene cloning and E. coli BL21 (DE3) serving as an expression host were purchased from TaKaRa Biotechnology Co. Ltd (Dalian, China). E. coli strains were routinely grown in LB broth or on LB agar plates with $100 \mu \mathrm{g} / \mathrm{ml}$ of ampicillin at $37{ }^{\circ} \mathrm{C}$. The pMD19-T vector and pET-22b (+) vector were purchased from Invitrogen Corp. (Shanghai, China), and used for cloning and expression studies, respectively.

DNA Marker, Protein Marker, GoldView, T4 DNA ligase, PrimeSTAR HS DNA Polymerase, QuickCutTM Nde I and QuickCutTM Xho I restriction enzymes were purchased from TaKaRa Biotechnology Co., Ltd (Dalian, China). A bacterial genome extraction kit, a DNA fragment purification kit, an agarose gel DNA purification kit and a MiniBEST Plasmid Purification Kit were purchased from Sangon Biotechnology Co., Ltd. (Shanghai, China). All aqueous solutions and buffers were prepared with water purified with an in-house Milli-Q Plus System (Millipore, Inc., Billerica, MA, USA). All the other chemicals were of analytical grade.

\section{Cloning of ftsZ gene}

The genomic DNA of $X$. oryzae pv. Oryzae was extracted using the bacterial genome extraction kit according to the manual's instructions. The $f t s Z$ gene was amplified from the genomic DNA of $X$. oryzae pv. Oryzae by PCR with forward primer 5'-GGAATTCCATATGGCACATTTCGAACTGATTG-3' and reverse primer 5'-CCGCTCGAGGTCGGCCTGGCGGCGCAGG-3' (Nde I and Xho $I$ restriction sites are underlined). The amplification conditions were as follows: denaturation for $1 \mathrm{~min}$ at $94^{\circ} \mathrm{C}$ and then 30 cycles of $30 \mathrm{~s}$ at $94{ }^{\circ} \mathrm{C}, 30 \mathrm{~s}$ at $57{ }^{\circ} \mathrm{C}$, and $90 \mathrm{~s}$ at $72{ }^{\circ} \mathrm{C}$. The PCR product was verified by $1 \%$ agarose gel electrophoresis and then extracted using the DNA fragment purification kit based on the manufacturer's instructions. The product was cloned between the Nde I and Xho I sites of pMD19-T vector and confirmed by plasmid PCR and DNA sequencing.

\section{Construction of recombinant expression vector}

The TA-cloned pMD19-fts $Z$ was digested by Nde I and Xho I restriction enzymes and followed ligation with the Nde $\mathrm{I} /$ Xho I digested pET-22b (+) to produce pET-22b-fts $Z$. Finally, the recombinant plasmid was transformed into $E$. coli BL21 (DE3) with chemical transformation methods. The positive clones were identified by plasmid PCR and restriction enzymes digestion, and their DNA was verified by Sangon Biotechnology Co., Ltd (Shanghai, China).

\section{Expression and purification}

The FtsZ was over expressed according to the methods described below. Recombinant E. coli BL21 (DE3) harboring the expression plasmid of pET-22b-fts $Z$ was precultured in $5 \mathrm{ml} \mathrm{LB}$ broth medium with $100 \mu \mathrm{g} / \mathrm{ml}$ of ampicillin overnight at $37{ }^{\circ} \mathrm{C}$ on a rotary shaker at $200 \mathrm{r} /$ $\mathrm{min}$, and then inoculated at $2 \%(\mathrm{v} / \mathrm{v})$ into $250 \mathrm{ml}$ flasks 
containing $100 \mathrm{ml} \mathrm{LB}$ broth medium supplemented with $100 \mu \mathrm{g} / \mathrm{ml}$ of ampicillin for soluble expression of protein. When the $\mathrm{OD}_{600}$ reached approximately 0.6 , IPTG was added to $0.6 \mathrm{mM}$ to induce protein expression for an additional $3 \mathrm{~h}$ at $37^{\circ} \mathrm{C}$ on a rotary shaker at $200 \mathrm{r} / \mathrm{min}$.

The FtsZ was purified according to the methods described below. Recombinant E. coli BL21 (DE3) cells were collected by centrifugation at $8000 \mathrm{~g}$ for $5 \mathrm{~min}$ at $4{ }^{\circ} \mathrm{C}$, suspended in lysis buffer $(50 \mathrm{mM}$ Tris- $\mathrm{HCl}, \mathrm{pH}$ 8.0, with $100 \mathrm{mM} \mathrm{NaCl}$ and $200 \mu \mathrm{g} / \mathrm{ml}$ lysozyme) and lysed on ice by the sonication at $400 \mathrm{~W}$ for 99 cycles of $3 \mathrm{~s}$ working and $5 \mathrm{~s}$ intervals. The suspension was centrifuged at $12,000 \mathrm{~g}$ for $20 \mathrm{~min}$ at $4{ }^{\circ} \mathrm{C}$ to remove the cell debris. The supernatant was collected and loaded onto the Ni-NTA agarose column (His tag affinity column) to purify recombinant protein according to the instructions of the manufacturer. After non-specifically bound proteins had been washed out, the FtsZ was eluted with one volume of elution buffer (50 mM Tris- $\mathrm{HCl}, \mathrm{pH}$ 8.0, with $100 \mathrm{mM} \mathrm{NaCl}$, and $500 \mathrm{mM}$ imidazole). Finally, the FtsZ was dialyzed against buffer solution $(50 \mathrm{mM}$ Tris $\mathrm{pH} 8.0,5 \mathrm{mM} \mathrm{MgCl}_{2}$ and $250 \mathrm{mM} \mathrm{KCl}$ ) at $4{ }^{\circ} \mathrm{C}$ overnight and concentrated with polyethylene glycol 8000. The concentration of the purified FtsZ was determined by the Coomassie brilliant blue method with bovine serum albumin (BSA) as a standard and then stored at $-20{ }^{\circ} \mathrm{C}$ for further study.

\section{SDS-PAGE}

The protein samples were mixed with $4 \times$ SDS-PAGE loading buffer at the ratio $3: 1(\mathrm{v} / \mathrm{v})$ and boiled for $5 \mathrm{~min}$. The samples were run on $12 \%$ SDS-PAGE gels at $100 \mathrm{~V}$ for 90 min with the Bio-Rad mini protein system (BioRad Laboratories). The resolved protein samples were visualized by staining with Coomassie brilliant blue.

\section{Western blotting analysis}

The presence of FtsZ in the purified fractions was confirmed by the western blotting analysis. For the western blotting, proteins were separated by SDS-PAGE on $12 \%$ gel at $100 \mathrm{~V}$ for $60 \mathrm{~min}$ and transferred onto PVDF membrane (Bio-Rad) treated with methanol in transfer buffer (48 mM Tris, $39 \mathrm{mM}$ glycine, $0.0375 \%$ SDS, and $20 \%$ $(\mathrm{v} / \mathrm{v})$ methanol) at room temperature, $67 \mathrm{~mA}$ for $1 \mathrm{~h}$. Then the membrane was blocked with $5 \%$ non-fat milk in PBS for $1 \mathrm{~h}$ at room temperature. After being washed twice with PBS Tween/Triton $(20 \mathrm{mM}$ Tris, $500 \mathrm{mM}$ $\mathrm{NaCl}, 0.05 \%$ Tween 20, and $0.2 \%$ Triton X-100) and three times with PBS, the membrane was incubated for another hour with mouse anti-His antibody at a dilution of 1:5000 in PBS. After being washed four times with PBS, the membrane was incubated for $30 \mathrm{~min}$ with goat anti-mouse IgG antibody at a dilution of 1:5000 in PBS.
After being washed four times with PBS, the membrane was taken into the DAB substrate solution. Then the target proteins were visualized with the enhanced chemiluminescence detection system.

\section{Bioinformatics analysis}

The nucleotide and the predicted amino acid sequence were analyzed online (http://www.ncbi.nlm.nih.gov and http://www.expasy.org/proteomics), and the sequence comparison was conducted with the BLAST tool to find the homology of $X$. oryzae pv. Oryzae FtsZ with other FtsZ (http://www.ncbi.nlm.nih.gov). Swiss-Model analysis was also performed (http://swissmodel.expasy. org/). DNAMAN and MEGA5.1 software were used for sequence and phylogenetic analysis with the neighbourjoining method.

\section{GTPase activity assay}

The GTPase activity of FtsZ was measured in a 96-well microplate with the malachite green method (Salvarelli et al. 2011). Reactions were carried out in $200 \mu \mathrm{l}$ buffer solution $(50 \mathrm{mM}$ Tris, $5 \mathrm{mM} \mathrm{MgCl}, 250 \mathrm{mM} \mathrm{KCl}, \mathrm{pH}$ 7.5) with $5 \mathrm{mM} \mathrm{GTP}$, and initiated by the addition of FtsZ at $37^{\circ} \mathrm{C}$. After $30 \mathrm{~min}$, the reactions were quenched by adding $40 \mu \mathrm{l}$ of above buffer solution containing EDTA $(65 \mathrm{mM})$. The green malachite-molybdate reagent was added and absorbance at $620 \mathrm{~nm}$ was measured. A phosphate standard curve was done with $\mathrm{Na}_{2} \mathrm{HPO}_{4}$. The GTPase activity of FtsZ was determined from the slope of the linear part of the phosphate accumulation curve. One $\mathrm{U}$ of GTPase activity of FtsZ is defined as the amount of FtsZ required for the catalytic reaction to release $1 \mu \mathrm{mol}$ Pi from GTP in $1 \mathrm{~min}$. All experiments were performed in triplicate.

\section{Enzyme characterization}

The optimum temperature for GTPase activity of FtsZ was determined by the GTPase activity assay with $5 \mathrm{mM}$ GTP in buffer solution (pH7.0) as substrate at temperature range of $20-70{ }^{\circ} \mathrm{C}$, thermal stability of FtsZ was determined by the retained GTPase activity after incubation at $4-60^{\circ} \mathrm{C}$ for $240 \mathrm{~min}$.

The optimum $\mathrm{pH}$ for GTPase activity of FtsZ was determined by the GTPase activity assay with $5 \mathrm{mM}$ GTP as substrate in the $\mathrm{pH}$ range of 4.0-10.0 at optimum temperature.

The effect of $\mathrm{Mg}^{2+}$ on GTPase activity of the recombinant FtsZ was determined by measuring the GTPase activity of the recombinant FtsZ in the presence of $\mathrm{Mg}^{2+}$ at final concentration of $5 \mathrm{mM}$ using the GTPase activity assay under the optimum temperature and $\mathrm{pH}$.

Michaelis-Menten kinetic experiments on GTPase activity of FtsZ were performed with final concentration 
of 1-10 mM GTP as substrate at optimum temperature and $\mathrm{pH}$, and the kinetics $\mathrm{K}_{\mathrm{M}}$ and $\mathrm{V}_{\max }$ were calculated.

\section{Authors' contributions}

LD and YC - Participated in all research work and framing manuscript. YHHParticipated in partial research work and framing the manuscript. ZL-Participated in partial research work and framed the manuscript. All authors read and approved the final manuscript.

\section{Acknowledgements}

The authors acknowledge financial support from the National Natural Science Foundation of China (Nos. 31160029 and 31360018), the Natural Science Foundation of Jiangxi Province (Nos. 20122BAB204008 and 20132BAB204007) and Special Fund for Agro-scientific Research in the Public Interest (No. 201203072).

\section{Competing interests}

The authors declare that they have no competing interests.

Received: 9 October 2015 Accepted: 16 February 2016

Published online: 24 February 2016

\section{References}

Bi EF, Lutkenhaus J (1991) FtsZ ring structure associated with division in Escherichia coli. Nature 354:161-164

Byul PS, Lee IA, Suh JW, Kim JG, Lee CH (2011) Screening and identification of antimicrobial compounds from Streptomyces bottropensis suppressing rice bacterial blight. J Microbiol Biotechnol 21:1236-1242

Chan FY, Sun N, Neves MA, Lam PC, Chung WH, Wong LK, Chow HY, Ma DL, Chan PH, Leung YC, Chan TH, Abagyan R, Wong KY (2013) Identification of a new class of FtsZ inhibitors by structure-based design and in vitro screening. J Chem Inf Model 53:2131-2140

Davies J (2011) How to discover new antibiotics: harvesting the parvome. Curr Opin Chem Biol 15:5-10

González JF, Degrassi G, Devescovi G, De VD, Höfte M, Myers MP, Venturi V (2012) A proteomic study of Xanthomonas oryzae pv. oryzae in rice xylem sap. J Proteomics 75:5911-5919

Haydon DJ, Stokes NR, Ure R, Galbraith G, Bennett JM, Brown DR, Baker PJ, Barynin WV, Rice DW, Sedelnikova SE, Heal JR, Sheridan JM, Aiwale ST, Chauhan PK, Srivastava A, Taneja A, Collins I, Errington J, Czaplewski LG (2008) An inhibitor of FtsZ with potent and selective anti-staphylococcal activity. Science 321:1673-1675
Kaur S, Modi NH, Pand D, Roy N (2010) Probing the binding site of curcumin in Escherichia coli and Bacillus subtilis FtsZ: a structural insight to unveil antibacterial activity of curcumin. Eur J Med Chem 45:4209-4214

Kiran M, Maloney E, Lofton H, Chauhan A, Jensen R, Dziedzic R, Madiraju M, Rajagopalan M (2009) Mycobacterium tuberculosis fts $Z$ expression and minimal promoter activity. Tuberculosis 89:S60-S64

Margalit DN, Romberg L, Mets RB, Hebert AM, Mitchison TJ, Kirschner MW, RayChaudhuri D (2004) Targeting cell division: small-molecule inhibitors of FtsZ GTPase perturb cytokinetic ring assembly and induce bacterial lethality. Proc Natl Acad Sci USA 707:11821-11826

Mew TW, Alvare AM, Leach JE (1993) Focus on bacterial blight of rice. Plant Dis $77: 5-12$

Modia KM, Tewarib R, Misra HS (2014) FtsZ sistant bacterium Deinococcus radiodurans is characterized as a GTPase exhibiting polymerization/depolymerization dynamics in vitro and FtsZ ring formation in vivo. Int J Biochem Cell Biol 50:38-46

Salvarelli E, Krupk M, Rivas G, Vicente M, Mingorance J (2011) Independence between GTPase active sites in the Escherichia coli cell division protein FtsZ. FEBS Lett 585:3880-3883

Sass P, Josten M, Famulla K, Schiffer G, Sahl HG, Hamoen L, Brotz-Oesterhelt H (2011) Antibiotic acyldepsipeptides activate ClpP peptidase to degrade the cell division protein FtsZ. Proc Natl Acad Sci USA 108:17474-17479

Shin JY, Vollmer W, Lagos R, Monasterio O (2013) Glutamate 83 and arginine 85 of helix $\mathrm{H} 3$ bend are key residues for Fts $Z$ polymerization, GTPase activity and cellular viability of Escherichia coli: lateral mutations affect FtsZ polymerization and E. coli viability. BMC Microbiol 13:26

Sossong TM, Brighamburke MR, Hensley P, Pearce KH Jr (1999) Self-activation of guanosine triphosphatase activity by oligomerization of the bacterial cell division protein FtsZ. Biochemistry 38:14843-14850

Thakur M, Chakraborti PK (2006) GTPase activity of mycobacterial FtsZ is impaired due to its transphosphorylation by the eukaryotic-type Ser/Thr kinase. PknA J BiolChem 281:40107-40113

Wu Y, Huang YH, Peng WM, Long ZE (2013) Effect of Antibiotics from a strain of Micromonospora carbonacea on cell morphology and protein synthesis of Xanthomonas oryzae pv. Oryzae. J Pure Appl Microbiol 7:2987-2991

Zhu XF, Xu Y, Peng D, Zhang Y, Huang TT, Wang JX, Zhou MG (2013) Detection and characterization of bismerthiazol-resistance of Xanthomonas oryzae pv. Oryzae. Crop Prot 47:24-29

\section{Submit your manuscript to a SpringerOpen ${ }^{\odot}$ journal and benefit from:}

- Convenient online submission

- Rigorous peer review

- Immediate publication on acceptance

- Open access: articles freely available online

- High visibility within the field

- Retaining the copyright to your article

Submit your next manuscript at $>$ springeropen.com 